\title{
No association of three GRIN2B polymorphisms with lithium response in bipolar patients
}

\author{
Aleksandra Szczepankiewicz ${ }^{1,3}$, Maria Skibińska ${ }^{1}$, Aleksandra Suwalska² \\ Joanna Hauser ${ }^{1,2}$, Janusz K. Rybakowski² \\ ${ }^{1}$ Psychiatric Genetics Unit, Department of Psychiatry; Poznań University of Medical Sciences, Poland \\ ${ }^{2}$ Department of Adult Psychiatry, Poznań University of Medical Sciences, Poland \\ ${ }^{3}$ Department of Pulmonology, Pediatric Allergy and Clinical Immunology, Poznań University of Medical Sciences, \\ Poland
}

Correspondence: Aleksandra Szczepankiewicz, e-mail: alszczep@amp.edu.pl

\begin{abstract}
:
We investigated three polymorphisms in the NMDA receptor 2B subunit gene (GRIN2B) as a candidate gene for lithium response involved in glutamatergic neurotransmission. One hundred five bipolar patients treated with lithium for at least 5 years were analyzed. The lithium response was assessed as excellent - no affective episodes during lithium treatment; partial - 50\% reduction in the episode index; or no response - less than 50\% reduction, no change or worsening in the episode index. Genotypes for the $-200 \mathrm{G} / \mathrm{T}$, 366C/G and rs890G/T GRIN2B polymorphisms were established using the PCR-RFLP method. Genotype distributions were in Hardy-Weinberg equilibrium for all three polymorphisms. No association was found between the three polymorphisms studied and the treatment response to lithium. The authors conclude that polymorphisms of the GRIN2B gene did not show an association with the treatment response to lithium in bipolar patients.
\end{abstract}

Key words:

lithium response, bipolar disorder, GRIN2B gene, polymorphism

\begin{abstract}
Abbreviations: ER - excellent lithium responders, GRIN2B glutamate receptor, ionotropic, NMDA - N-methyl-D-aspartate, $\mathrm{NR}$ - non-responders to lithium, PCR - polymerase chain reaction, PR - partial lithium responders, RFLP - restriction fragments length polymorphism
\end{abstract}

\section{Introduction}

Lithium has been using as a mood-stabilizer in the treatment of bipolar disorders since the 1960s. In re- cent years, it has been indicated that lithium may affect the biophysical properties of ionotropic glutamate receptors [6, 7]. It was also established that lithium exerts its neuroprotective effect through the reduction of NMDA receptor-induced excitotoxicity [5, 12]. This has been confirmed in animal models where radio-ligand binding of [3H]-MK801 or other NMDA receptor antagonists was decreased in the cerebral cortex of mice after the chronic administration of antidepressant drugs $[8,14]$. Moreover, it has been found that lithium indirectly reduces pro-apoptotic function in neurons by inhibiting N-methyl-D-aspartate 
Tab. 1. Clinical description of the patients

\begin{tabular}{lcccc}
\hline & Total & ER & PR & NR \\
$n=105$ & $n=24$ & $n=53$ & $n=28$ \\
\hline Age years [mean \pm SD] & $52.4 \pm 11.9$ & $56.0 \pm 12.6$ & $50.7 \pm 11.8$ & $52.4 \pm 11.8$ \\
Gender [M:F] & $42: 63$ & $11: 13$ & $20: 33$ & $11: 17$ \\
Family history of psychiatric illness N (\%) & $41(40.5 \%)$ & $11(45.8 \%)$ & $24(47.0 \%)$ & $6(23.0 \%)$ \\
Age at onset - years [mean \pm SD] & $29.6 \pm 9.3$ & $29.6 \pm 8.8$ & $29.5 \pm 9.4$ & $30.1 \pm 9.9$ \\
Duration of illness before lithium - years [mean \pm SD] & $7.4 \pm 7.4$ & $9.7 \pm 9.6$ & $5.6 \pm 5.9$ & $8.7 \pm 6.0$ \\
Duration of lithium treatment - years [mean \pm SD] & $14.6 \pm 7.3$ & $14.0 \pm 7.1$ & $15.3 \pm 7.9$ & $13.8 \pm 5.8$ \\
Affective episodes before lithium N [mean \pm SD] & $6.2 \pm 4.1$ & $7.0 \pm 3.6$ & $6.0 \pm 4.5$ & $5.8 \pm 3.9$ \\
Affective episodes on lithium N [mean \pm SD] & $3.3 \pm 3.9$ & 0 & $3.5 \pm 2.7$ & $8.2 \pm 4.8$ \\
\hline
\end{tabular}

(NMDA)-receptor-mediated calcium influx [12], and this action appears to be associated with changes in NMDA receptor subunit levels [4, 12]. In cortical neurons, such calcium influx inhibition is correlated with a decrease in GRIN2B phosphorylation [4].

The gene encoding the NR2B receptor subunit (GRIN2B) is localized in the chromosomal region (12p12) previously linked to bipolar disorder [2]. The GRIN2B gene is mainly expressed in forebrain structures such as the hippocampus, striatum, thalamus and olfactory bulb [17]. Its altered expression at the protein level has been observed in bipolar disorder [16]; however, it was not confirmed by a recent study by Martucci et al. [9].

We hypothesized that polymorphisms in the GRIN2B gene might lead to a dysfunction of the glutamate receptor system and alter the response to lithium treatment. Since there have been no studies of GRIN2B polymorphisms and lithium response thus far, we aimed to analyze the three GRIN2B gene variants with regard to response to chronic lithium treatment in a group of 105 bipolar patients.

\section{Methods}

\section{Subjects}

In our analysis, we included a group of 105 patients with bipolar disorder (type I - 60 patients, type II - 45 patients) receiving lithium for prophylactic purposes. Consensus diagnosis by at least two psychiatrists was made for each patient according to DSM-IV and
ICD-10 criteria (SCID) [3]. The clinical description of the patients is presented in Table 1.

The patients were included only when they had been continuously taking lithium. The duration of lithium administration ranged from 5-27 years (mean 15 years), and the patients were under the control of the outpatient clinic at the Department of Psychiatry at the University of Medical Sciences in Poznan throughout this period. The serum concentration of lithium was maintained in a range between $0.5-0.8 \mathrm{mmol} / \mathrm{l}$. If the patients needed hospitalization, they were hospitalized in the same institution (inpatient clinic, Department of Adult Psychiatry, University of Medical Sciences in Poznań).

The level of responsiveness to lithium prophylaxis was assessed according to the following criteria: excellent lithium responders (ER) had no affective episodes on lithium; partial lithium responders (PR) showed a 50\% reduction in the episode index (number of episodes per year to pre-lithium period); and lithium non-responders (NR) showed $<50 \%$ reduction, no change or worsening in the episode index [15]. All excellent lithium responders did not receive any drugs other than lithium throughout the period of observation. In the remaining patients, antidepressant, neuroleptic and other mood-stabilizing drugs were temporarily added for the treatment of their depressive, manic or mixed episodes and for improving the prophylactic effect. At the time of study, among the PR and NR patients, 17 had been concomitantly receiving carbamazepine, 5 - valproate, 11 - antidepressant drugs and 9 - neuroleptic drugs for a period of several years.

After complete description of the study to the subjects, written informed consent was obtained. The study was approved by the Local Bioethics Commit- 
tee and was performed in compliance with the Code of Ethics of the World Medical Association (Declaration of Helsinki).

\section{Genotyping}

DNA was extracted from $10 \mathrm{ml}$ of EDTA anticoagulated whole blood using the salting out method [10].

The three GRIN2B polymorphisms, 366C/G (Pro122) (rs7301328), rs890G/T and -200T/G (rs1019358), were analyzed by PCR-RFLP analysis according to Ohtsuki et al. [13], with minor modifications. The SNP selection was based on the functionality of the $-200 \mathrm{G} / \mathrm{T}$ polymorphism $[9,11]$ and the fact that the other two polymorphisms (rs7301328 and rs890) showed positive association with schizophrenia [1, 13], which may have some common genetic background with bipolar disorder.

PCR was performed in a PTC-200 (MJ Research) thermal cycler. A $15 \mu 1$ amplification mixture for each polymorphism contained $250 \mathrm{ng}$ of genomic DNA, $0.45 \mu \mathrm{M}$ of each primer, $0.17 \mathrm{mM}$ of each dNTP, $1.5 \mathrm{mM}$ $\mathrm{MgCl}_{2}, 75 \mathrm{mM}$ Tris- $\mathrm{HCl}, 20 \mathrm{mM}\left(\mathrm{NH}_{4}\right)_{2} \mathrm{SO}_{4}, 0.01 \%$ Tween and $0.5 \mathrm{U}$ of Taq DNA polymerase (MBI Fermentas). The cycling conditions were: initial denaturation at $95^{\circ} \mathrm{C}$ for 2 min followed by 30 cycles with a profile of $94^{\circ} \mathrm{C}$ for $30 \mathrm{~s}, 56^{\circ} \mathrm{C}(366 \mathrm{C} / \mathrm{G}$ polymorphism), $58^{\circ} \mathrm{C}$ (rs890G/T polymorphism) or $64^{\circ} \mathrm{C}$ $(-200 \mathrm{~T} / \mathrm{G})$ for $30 \mathrm{~s}, 72^{\circ} \mathrm{C}$ for $30 \mathrm{~s}$, and a final elongation at $72^{\circ} \mathrm{C}$ for $5 \mathrm{~min}$. A volume of $5 \mu \mathrm{l}$ of each PCR product $(112 \mathrm{bp}$ for $366 \mathrm{C} / \mathrm{G}$; $196 \mathrm{bp}$ for $\mathrm{rs} 890 \mathrm{G} / \mathrm{T}$ and $159 \mathrm{bp}$ for $-200 \mathrm{~T} / \mathrm{G}$ ) was then digested overnight in a total volume of $10 \mu 1$ at $37^{\circ} \mathrm{C}$ with $0.5 \mathrm{U}$ of the appropriate restriction endonuclease (TaqI for the $366 \mathrm{C} / \mathrm{G}$ polymorphism, PsuI for the rs $890 \mathrm{G} / \mathrm{T}$ polymorphism and HpaII for the $-200 \mathrm{~T} / \mathrm{G}$ polymorphism). After RFLP analysis, the following alleles were observed: for the $366 \mathrm{C} / \mathrm{G}$ polymorphism, allele $\mathrm{C}$ (uncut PCR product - $112 \mathrm{bp}$ ) and allele G (93 and $12 \mathrm{bp}$ ); for the rs $890 \mathrm{G} / \mathrm{T}$ polymorphism, allele T (uncut PCR product - $196 \mathrm{bp}$ ) and allele $\mathrm{C}$ (136 and $60 \mathrm{bp}$ ); for the $-200 \mathrm{~T} / \mathrm{G}$ polymorphism, allele $\mathrm{G}(101,37$ and 21 bp) and allele $\mathrm{T}$ (122 and $37 \mathrm{bp}$ ). The uncut PCR products for $366 \mathrm{C} / \mathrm{G}$ and $\mathrm{rs} 890 \mathrm{G} / \mathrm{T}$ were digested twice to confirm the results. A control of RFLP analysis was also performed $(25 \%$ of randomly chosen samples from both groups).

\section{Statistical analysis}

The two-tailed Pearson's chi-square $\left(\chi^{2}\right)$ test and Fisher's exact test were used to test differences in the genotypic and allelic (respectively) distribution between excellent responders, partial responders, and non-responders to lithium treatment. Calculations were done using the computer program Statistica version 7.1. For polymorphisms containing $<5$ observations per cell, we performed the Freeman-Halton exact test with the use of StatsDirect statistical software v.2.6.2 (trial). Odds ratios were calculated using a demo version of the GraphPad InStat 3 program. For the analysis of lithium response between excellent, partial and non-responders, we performed Bonferroni's correction to adjust the significance level for multiple testing. Power analysis was performed using the program QUANTO v. 1.2.

\section{Results}

The genotype distribution was in Hardy-Weinberg equilibrium for all of the studied polymorphisms $(\mathrm{p}=0.457$ for $366 \mathrm{C} / \mathrm{G}, \mathrm{p}=0.190$ for $\mathrm{rs} 890 \mathrm{G} / \mathrm{T}$ and $\mathrm{p}=0.874$ for $-200 \mathrm{G} / \mathrm{T})$ in the group of bipolar patients treated with lithium. To test differences between genotype distributions, we applied Pearson's test $(3 \times 2$ contingency tables). To analyze differences in allele frequencies, we performed Fischer's exact test $(2 \times 2$ contingency tables). To estimate the size of the genetic effect on phenotype, we performed odds ratio calculations.

We observed a significant difference in allele frequencies for $\mathrm{rs} 890$ polymorphism $(\mathrm{p}=0.018)$. However, after correction for multiple testing, this difference was no longer significant (for $\mathrm{k}=3$ groups, the corrected significance level was 0.016 ). In the analysis of association between the other two GRIN2B polymorphisms with the response to lithium, we did not find any statistically significant differences in genotype distribution or allele frequencies between the excellent-, partial- and non-responders (Table 2).

Odds ratios calculated with the $95 \%$ CI were the following: $\mathrm{OR}=1.11(95 \% \mathrm{CI}=0.60-2.06)$ for $-200 \mathrm{G} / \mathrm{T} ; \quad \mathrm{OR}=0.84(95 \% \mathrm{CI}=0.45-1.56)$ for $366 \mathrm{C} / \mathrm{G}$; and $\mathrm{OR}=0.86(95 \% \mathrm{CI}=0.46-1.73)$ for rs $890 \mathrm{G} / \mathrm{T}$. 
Tab. 2. Genotype distributions and allele frequencies of the three analyzed polymorphisms of the GRIN2B gene for bipolar patients with different lithium response (figures in parentheses indicate percentages)

\begin{tabular}{|c|c|c|c|c|c|c|}
\hline \multicolumn{3}{|c|}{ Polymorphism } & \multirow{2}{*}{$\begin{array}{c}\text { ER } \\
9(37.50) \\
10(41.67) \\
5(20.83)\end{array}$} & \multirow{2}{*}{$\begin{array}{c}\text { PR } \\
15(27.78) \\
29(53.70) \\
9(16.67)\end{array}$} & \multirow{2}{*}{$\begin{array}{c}\text { NR } \\
9(32.14) \\
16(57.14) \\
310.71)\end{array}$} & \multirow{2}{*}{$\begin{array}{c}\text { p value } \\
0.809\end{array}$} \\
\hline $366 C / G$ & genotypes & $\begin{array}{l}C C \\
C G \\
G G\end{array}$ & & & & \\
\hline & alleles & $\begin{array}{l}C \\
G\end{array}$ & $\begin{array}{l}28(58.33) \\
20(41.67)\end{array}$ & $\begin{array}{l}59(55.66) \\
47(44.34)\end{array}$ & $\begin{array}{l}34(60.71) \\
22(39.29)\end{array}$ & 0.782 \\
\hline \multirow[t]{2}{*}{$\mathrm{rS} 890 \mathrm{G} / \mathrm{T}$} & genotypes & $\begin{array}{l}\text { TT } \\
\text { TG } \\
\text { GG }\end{array}$ & $\begin{array}{c}8(36.36) \\
11(50.00) \\
3(13.64)\end{array}$ & $\begin{array}{c}13(25.49) \\
31(60.78) \\
7(13.73)\end{array}$ & $\begin{array}{c}9(36.00) \\
12(48.00) \\
4(16.00)\end{array}$ & 0.806 \\
\hline & alleles & $\begin{array}{l}\mathrm{T} \\
\mathrm{G} \\
\end{array}$ & $\begin{array}{l}27(61.36) \\
17(38.64) \\
\end{array}$ & $\begin{array}{l}57(55.88) \\
45(44.12)\end{array}$ & $\begin{array}{l}30(60.00) \\
20(40.00)\end{array}$ & 0.018 \\
\hline \multirow[t]{2}{*}{$-200 T / G$} & genotypes & $\begin{array}{l}\mathrm{GG} \\
\mathrm{GT} \\
\mathrm{TT}\end{array}$ & $\begin{array}{c}6(25.00) \\
14(58.33) \\
4(16.67)\end{array}$ & $\begin{array}{l}18(33.96) \\
22(41.51) \\
13(24.53)\end{array}$ & $\begin{array}{c}6(21.43) \\
17(60.71) \\
5(17.86)\end{array}$ & 0.473 \\
\hline & alleles & $\begin{array}{l}\mathrm{T} \\
\mathrm{C}\end{array}$ & $\begin{array}{l}26(54.17) \\
22(45.83)\end{array}$ & $\begin{array}{l}58(54.72) \\
48(45.28)\end{array}$ & $\begin{array}{l}29(51.79) \\
27(48.21)\end{array}$ & 0.660 \\
\hline
\end{tabular}

When we pooled the patients with excellent and partial response versus non-responders, we did not observe any association with the GRIN2B polymorphisms analyzed in this study (for the $366 \mathrm{C} / \mathrm{G}$ polymorphism, $p=0.741$ for genotypes and $p=0.637$ for alleles; for the rs $890 \mathrm{G} / \mathrm{T}$ polymorphism, $\mathrm{p}=0.706$ for genotypes and $\mathrm{p}=0.868$ for alleles; and for the $-200 \mathrm{G} / \mathrm{T}$ polymorphism, $\mathrm{p}=0.438$ for genotypes and $\mathrm{p}=0.755$ for alleles).

The sample presented a power of less than $10 \%$ to detect a small effect size $(\mathrm{ORs}<1.2)$ at the statistical significance level of $5 \%$, so we had very limited power to detect small effects in our study. Based on the insufficient power, false negative results cannot be excluded.

\section{Discussion}

The main finding of this study is a lack of association between lithium response and the GRIN $2 B$ polymorphisms analyzed in our carefully characterized group of 105 bipolar patients (excellent, partial and nonresponders to lithium) taking lithium for 5-27 years (mean 15 years). To our knowledge, no other studies on the relationship between GRIN2B polymorphisms and lithium response are available, so we cannot compare our results.
We assumed that polymorphisms in the GRIN2B gene may affect the prophylactic response to lithium based on the results of experimental studies. It has been shown that chronic exposure to therapeutically relevant concentrations of lithium decreases NMDAinduced currents in hippocampal cultures, decreases phosphorylation of the NR-2B subunit and decreases NMDA-induced calcium influx in cerebral cortical neurons [4]. However, in molecular-genetic studies, the functionality of only the $-200 \mathrm{~T} / \mathrm{G}$ polymorphism has been described. This variant was found to be localized in the putative Sp1 binding site in the 5'upstream region of the GRIN2B gene, and different luciferase reporter activity was found for different alleles, suggesting that this region is crucial for GRIN2B regulation [11]. For the other two polymorphisms, there are no experimental data on their importance in gene regulation; however, such influence cannot be excluded.

There are several limitations of the present study. First of all, our sample is relatively small, particularly after stratification by response, to detect an association, as indicated by the low power values for the analyzed polymorphisms. Therefore, further breakdown of the group into bipolar I and bipolar II patients would not be reasonable. For the rs890G/T polymorphism, we observed a marginal significance that disappeared after correcting for multiple testing. We may only assume that a further increase of our sample would decrease the p-value, such that it reaches sig- 
nificance even after correction. However, to achieve a power of $80 \%$ and exclude false negative results, the sample size at a given odds ratio value should be increased to more than 10,000 bipolar patients on lithium. Therefore, false negative results cannot be ruled out when taking into account the low power of this study. Moreover, in the case of lithium pharmacogenetics, it is more difficult to get a large sample size of bipolar patients with good quality response criteria. Our group is one of the largest in the field of lithium pharmacogenetics and has one of the longest lithium treatment observations (at least five years). Among other limitations of the present analysis, we should also mention that the picture of an association between GRIN2B polymorphism and response to lithium may also be confounded by the fact that some patients in the PR and NR groups were also treated with carbamazepine, valproate, antidepressant or neuroleptic drugs.

We can conclude that the three GRIN2B polymorphisms analyzed here did not show an association with response to long-term lithium treatment in our sample of bipolar patients. However, based on the aforementioned limitations, further studies on a larger sample size or meta-analysis of the GRIN2B gene and lithium response would be necessary to verify our results. Also, a more comprehensive screen of GRIN2B polymorphisms could be useful in determining the involvement of the GRIN2B gene in lithium response.

\section{Acknowledgments:}

This study was supported by the Polish Committee of Scientific Research, grant no. N402 086 31/2644. Dr. Aleksandra Szczepankiewicz is the recipient of a 2008 Annual Fellowship for Young Scientists from the Foundation for Polish Science (FNP)

\section{References:}

1. Di Maria E, Gulli R, Begni S, De Luca A, Bignotti S, Pasini A, Bellone $\mathrm{E}$ et al.: Variations in the NMDA receptor subunit 2B gene (GRIN2B) and schizophrenia: a casecontrol study. Am J Med Genet B Neuropsychiatr Genet, 2004, 128B, 27-29.

2. Faraone SV, Su J, Tsuang MT: A genome-wide scan of symptom dimensions in bipolar disorder pedigrees of adult probands. J Affect Disord, 2004, 82, Suppl 1, S71-78.

3. First MB, Spitzer RL, Gibbon M, Williams J: Structured Clinical Interview for DSM-IV Axis I Disorders, Clinician Version (SCID-CV). American Psychiatric Press, Washington, D.C, 1996.
4. Hashimoto R, Hough C, Nakazawa T, Yamamoto T, Chuang DM: Lithium protection against glutamate excitotoxicity in rat cerebral cortical neurons: involvement of NMDA receptor inhibition possibly by decreasing NR2B tyrosine phosphorylation. J Neurochem, 2002, 80, 589-597.

5. Hokin LE, Dixon JF, Los GV: A novel action of lithium: stimulation of glutamate release and inositol 1,4,5trisphosphate accumulation via activation of the $\mathrm{N}$-methyl D-aspartate receptor in monkey and mouse cerebral cortex slices. Adv Enzyme Regul, 1996, 36, 229-244.

6. Karkanias NB, Papke RL: Lithium modulates desensitization of the glutamate receptor subtype gluR3 in Xenopus oocytes. Neurosci Lett, 1999, 277, 153-156.

7. Karkanias NB, Papke RL: Subtype-specific effects of lithium on glutamate receptor function. J Neurophysiol, 1999, 81, 1506-1512.

8. Kitamura Y, Zhao XH, Tekei M, Yonemitsu O, Nomura Y: Effects of antidepressants on the glutamatergic system in the mouse brain. Neurochem Int, 1991, 19, 247-253.

9. Martucci L, Wong AH, De Luca V, Likhodi O, Wong GW, King N, Kennedy JL: N-methyl-D-aspartate receptor NR2B subunit gene GRIN2B in schizophrenia and bipolar disorder: Polymorphisms and mRNA levels. Schizophr Res, 2006, 84, 214-221.

10. Miller SA, Dykes DD, Polesky HF: A simple salting out procedure for extracting DNA from human nucleated cells. Nucleic Acids Res, 1988, 16, 1215.

11. Miyatake R, Furukawa A, Suwaki H: Identification of a novel variant of the human NR2B gene promoter region and its possible association with schizophrenia. Mol Psychiatry, 2002, 7, 1101-1106.

12. Nonaka S, Hough CJ, Chuang DM: Chronic lithium treatment robustly protects neurons in the central nervous system against excitotoxicity by inhibiting $\mathrm{N}$-methyl-D-aspartate receptor-mediated calcium influx. Proc Natl Acad Sci USA, 1998, 95, 2642-2647.

13. Ohtsuki T, Sakurai K, Dou H, Toru M, YamakawaKobayashi K, Arinami T: Mutation analysis of the NMDAR2B (GRIN2B) gene in schizophrenia. Mol Psychiatry, 2001, 6, 211-216.

14. Petrie RX, Reid IC, Stewart CA: The N-methyl-D-aspartate receptor, synaptic plasticity, and depressive disorder. A critical review. Pharmacol Ther, 2000, 87, 11-25.

15. Rybakowski JK, Suwalska A, Skibińska M, Szczepankiewicz A, Leszczyńska-Rodziewicz A, Permoda A, Czerski PM et al.: Prophylactic lithium response and polymorphism of the brain-derived neurotrophic factor gene. Pharmacopsychiatry, 2005, 38, 166-170.

16. Scarr E, Pavey G, Sundram S, MacKinnon A, Dean B: Decreased hippocampal NMDA, but not kainate or AMPA receptors in bipolar disorder. Bipolar Disord, 2003, 5, 257-264.

17. Schito AM, Pizzuti A, Di Maria E, Schenone A, Ratti A, Defferrari R, Bellone E et al.: mRNA distribution in adult human brain of GRIN2B, a N-methyl-D-aspartate (NMDA) receptor subunit. Neurosci Lett, 1997, 239, 49-53.

Received:

July 9, 2008; in revised form: March 28, 2009 